\title{
Career Calling as a Personal Resource Moderator between Environmental Demands and Burnout in Australian Junior Doctors
}

Peter A. Creed ${ }^{1}$, Mary Rogers ${ }^{2}$, Anna Praskova ${ }^{1}$, and Judy Searle ${ }^{3}$

${ }^{1}$ School of Applied Psychology and Menzies Health Institute Queensland Griffith University, Australia

${ }^{2}$ Department of Employment Relations and Human Resources, Griffith Business School, Griffith University, Australia

${ }^{3}$ School of Medicine, Griffith University, Australia

\section{PAPER CAN BE CITED AS:}

Creed, P. A., Rogers, M., Praskova, A., \& Searle, J. (2014). Career calling as a personal resource moderator between environmental demands and burnout in junior doctors. Journal of Career Development, 41, 547-561. doi:10.1177/0894845313520493

Contact: $\quad$ Prof Peter Creed, PhD

School of Applied Psychology

Griffith University

Gold Coast, Qld, Australia 4222

p.creed@griffith.edu.au 


\begin{abstract}
We surveyed 355 junior doctors (first four years of post-university training; 69\% female, mean age $=28$ years) from multiple hospital and practice locations, and used an online questionnaire to assess their training-related demands (academic stress, concern about training debt, hours worked), academic burnout, and personal resources (operationalized as career calling). We tested whether training-related demands were associated with academic burnout and whether career calling moderated the association between the demands and burnout. The demands accounted for approximately one third of the variance in burnout, with all accounting for significant, unique variance. In the context of the demands, career calling was not a significant predictor, but it moderated the association between academic stress and burnout. The study identified additional ways that junior doctors can be assisted to manage these first few years of medical training after graduating from medical school.
\end{abstract}

Keywords: junior doctors; burnout; career calling; academic stress; concern about debt; hours worked; demands-resources model 


\section{Career Calling as a Personal Resource Moderator between Environmental Demands and Burnout in Australian Junior Doctors}

Burnout is a significant issue for junior medical doctors, who face long working hours, have a high patient load, and need to master complex procedural tasks and technologies in their first two years of medical training (de Oliva Costa, Santos, de Abreu Santos, de Melo, \& de Andrade, 2012; Dyrbye et al., 2011; Markwell \& Weiner, 2009), while at the same time managing an arduous academic workload (Colford \& McPhee, 1989; Wright et al., 2006). Researchers have begun to test for the correlates of burnout in this population, although this research is limited (de Oliva Costa et al., 2012), and there have been few studies that have assessed variables and conditions that might ameliorate the relation between the stressful training regime and burnout (Kushner, Kessler, \& McGaghie, 2011). The current study contributes to a better understanding of burnout in junior doctors by (a) testing the association between three important training demands (hours worked, academic stress, and concern about debt) and burnout, and (b) by assessing whether holding a strong focus and commitment to their profession (operationalized as career calling) reduces the relation between demands and burnout (i.e., moderates these relations).

\section{Burnout and Trainee Doctors}

Burnout is a chronic, negative psychological state, which has established links to stressrelated health outcomes, job withdrawal, and lower productivity (Goldberg et al., 1996; Maslach et al., 2001; Ozyurt, Hayran, \& Sur, 2006). It is the product of exposure to prolonged job-related demands, and is manifested in emotional and physical exhaustion, detachment from work, and a diminished sense of accomplishment (Maslach, Schaufeli, \& Leiter, 2001). It has especially worrying consequences for junior doctors, as it can lead to unprofessional and unethical behaviours, less interest in caring for the medically undeserving 
(Dyrbye, Massie et al., 2010), reduced empathy (Thomas et al., 2007), more medical errors (Prins et al., 2009; West et al., 2006), serious thoughts of dropping out of medicine (Dyrbye, Thomas et al., 2010), depression and suicidal ideation (Campbell, Prochazka, Yamashita, \& Gopal, 2010; Dyrbye et al., 2008, 2011; Martini, Arfken, Churchill, \& Balon, 2004), ill health and sleep disturbance that result in work absences (Kristensen, Borritz, Villadsen, \& Christensen, 2005), broken relationships, and substance abuse (Dyrbye et al., 2005; Levey, 2001). Consequently, burnout has implications for the well-being of junior doctors as well as for the quality of their health care.

The prevalence of burnout in medical trainees increases steadily during medical school (Galán, Sanmartín, Polo, \& Giner, 2011), continues to increase during postgraduate training, and peaks in residency (Campbell et al., 2010; Gelfand et al., 2004; Martini et al., 2004). Medical doctors in practice are more at risk of stress-related problems and poor well-being than the general population (Firth-Cozens, 2001); however, it is junior doctors who are most at risk of developing fatigue and burnout (Pesce, 2009). Martini et al. (2004) observed that half of the 110 junior doctors in their US study experienced burnout, while Campbell et al. (2010) reported that 78\% of US junior doctors experienced burnout at least once, and, Markwell and Wainer (2009) found, in a national survey of junior doctors in Australia, that $69 \%$ met the criteria for burnout and fatigue. As well as the demanding academic and patient workload and ever-increasing responsibilities, junior doctors typically have little autonomy (Campbell et al., 2010; Markwell \& Weiner, 2009), their learning environment is unstructured and sometimes chaotic, and they receive limited feedback on their performance (Colford \& McPhee, 1989; Wright et al., 2006). Work stress models (e.g., demand-control model; Karasek, 1979) suggest that work stress is higher when demands are accompanied by low decision latitude.

\section{Correlates of Burnout}


Three potentially important correlates of burnout in junior doctors are long working hours, academic stress, and concern about debt. Compared to training programs of other professionals, junior doctors work longer hours, have less time for sleep, personal relationships, and recreational activities (Heins, Fahey, \& Leiden, 1984; Levey, 2001). Markwell and Wainer (2009), for example, reported that 54\% of junior doctors believed that their work hours were excessive, that they regularly worked unsafe hours (31\%), and slept less per night than they needed (84\%). Junior doctors also face specific challenges in relation to academic stress (i.e., the negative psychological arousal resulting from academic demands that tax or exceed adaptive abilities; cf. Lazarus \& Folkman, 1984). After many years of structured education, they have little time for in-depth studying, must manage spontaneous teaching situations, often train in inhospitable or hostile environments (Colford \& McPhee, 1989; Cooke, 1985; Levey, 2001), lack the support and mentoring they need, often have poor quality supervision, and rarely receive debriefing after incidents (Abrau Santos, Grosseman, Oliva Costa, \& Andrade, 2011; Daly \& Willcock, 2002; Geurts, Rutte, \& Peeters, 1999). Finally, many junior doctors accumulate considerable financial burdens during their training (Colford \& McPhee, 1989). In the US, medical trainees are more concerned about the cost of their education now than they were five years ago (Correa, 2012), with more than half reporting that financial difficulties affect their training and quality of life (Collier, McCue, Markus, \& Smith, 2002). In Australia, medical trainees can accrue debts of more than AUD\$300,000, which must be repaid once they commence work (QTAC, 2013).

\section{Moderators of Burnout}

Long working hours, academic stress, and concern about debt, which, from a demandsresources model perspective (Demerouti, Bakker, Nachreiner, \& Schaufeli, 2001), can be considered as training demands and to be associated with burnout. However, not all medical trainees experience burnout (Campbell et al., 2010; Dyrbye et al., 2008), which suggests that 
there are other, "third” variables that play a role in buffering the effects of these stressors (i.e., moderate the relations). From the demands-resources model perspective, these third variables are considered resources, which are important in their own right (e.g., social support resources can increase motivation), but they also can operate to reduce the effects of stressproducing demands (Bakker, Demerouti, Taris, Schaufeli, \& Schreurs, 2003). While little work has examined moderators specific to junior doctors, selecting potential variables can be informed by the meta-analyses on general work-place burnout (e.g., Alarcon, Eschleman, \& Bowling, 2009; Halbesleben, 2010). In this study, we examine the effects of one potentially important moderator, that of having a positive, career-related focus, which we operationalize as having a career calling. There has been little research into the association between having a calling and well-being and burnout of junior doctors, although the general literature suggests that people who have a healthy, purposeful pursuit of their occupational goals manage better (Cardador \& Caza, 2012; Hall \& Chandler, 2005).

Individuals with a career calling approach their work with a strong sense of meaning and purpose, have a desire to contribute to the community (Dik \& Duffy, 2009; Elangovan, Pinder, \& McLean, 2010; Hall \& Chandler, 2005), are more engaged in their job, and miss fewer days at work (Duffy, Dik, \& Steger, 2011). For young people, a calling is associated with higher career expectations (Dik, Sargent, \& Steger, 2008), more confidence (Hirshi, 2011), and more motivation to pursue a career (Dobrow \& Tosti-Kharas, 2011). Specific to well-being, calling is associated with better general and career-related well-being and satisfaction (Duffy, Allan, \& Bott, 2012; Elangovan et al., 2010), reduced tension and more positive affect at work, better coping with work and career challenges (Cardador \& Caza, 2012), and less burnout (Hagmaier \& Abele, 2012). Specific to medical students, career calling was a salient construct for $48 \%$ of first year college students (Borges, Manuel, \& Duffy, 2013), and was associated with more life satisfaction (Duffy, Manuel, Borges, \& Bott, 
2011). While little research has examined career calling in junior doctors, related work demonstrates that having low future expectations, feeling uncomfortable in academic activities, not seeing training as a source of pleasure, and lacking confidence to acquire skills (which are aspects of a calling), are associated with more burnout (Oliva Costa, Santos, Abreu Santos, Melo, \& Andrade, 2012). Junior doctors with a stronger medical calling are likely to be more positive about their training, be more forgiving of negative aspects of training, and be more enthusiastic and motivated towards it, which should buffer the effects of the demanding training environment.

\section{The Present Study}

Based on the demands-resources model (Demerouti et al., 2001), we expected (a) that the three demands of academic stress, hours worked, and concerns about debt would be associated with higher levels of burnout in junior doctors, and (b) that the resource of having a higher career calling would buffer the association between demands and burnout. Specific hypotheses were:

Hypothesis 1: academic stress (H1a), hours worked (H1b), and concerns about debt (H1c) will be associated positively with burnout in junior doctors; and

Hypothesis 2: career calling will moderate the association between academic stress (H2a), hours worked (H2b), and concerns about debt (H2c) and burnout, with a stronger career calling weakening the association between the stressors and burnout.

\section{Method}

\section{Participants}

Participants were 355 junior doctors working in hospitals and general practices located across all States/Territories of Australia, who were in their first four years of their postgraduate, pre-vocational training. In these early post-graduate years, much of which is spent working in hospital settings, medical trainees build on their university training under the 
supervision of experienced medical and related health care practitioners. We distributed 472 questionnaires, giving a response rate of $75 \%$. There were 244 women (Mean age $=27.68$ years; Range $=22$ to 58) and 111 men (Mean age $=28.89$ years; Range $=21$ to 46$)$.

\section{Materials}

Burnout. We used the 7-item, work-related burnout subscale of the Copenhagen Burnout Inventory (Kristensen et al., 2005) to assess burnout. We modified some items to make them more relevant to medical trainees. Sample modified items included, "Do you feel worn out at the end of your medical training day?”, and “Are you exhausted in the morning at the thought of another day of medical training?’. Items were rated on a 5-point Likert-like scale with anchors of $0=$ never or almost never and 5 = always, with higher scores indicating greater burnout. The Inventory has been tested on international samples, including Australia, and validated against work sickness absences, sleep disturbances, pain-killer intake, and intention to leave the job (Kristensen et al., 2005; Winwood \& Winefield, 2004). Internal reliability for the work-related subscale has been reported at $>.80$. Alpha in our study was .88 .

Academic stress. Trainees completed a 4-item Academic Stress Scale, devised by Rogers, Creed, and Searle (2012), to assess levels of stress related to training workload and performance. Sample items included, "When I compare myself to others, I worry about how well I am doing”, and “I feel stressed about how I am performing”. Responses were made on a 5-point Likert-like scale, with anchors of 1 = strongly disagree and $5=$ strongly agree. Higher scores indicated more academic stress. Rogers et al. reported an internal reliability coefficient of .88 with medical students, and, in support of validity, found the scale to be associated negatively with a general measure of well-being and to be uncorrelated with personality factors of extraversion and neuroticism. Alpha in this study was .81 .

Concern about debt. We had trainees respond to the question, “At this stage of your medical education/training, how concerned are you about the level of debt you will have 
accrued at the end of your training?”, using a 4-point Likert-like scale with anchors of $1=$ not at all concerned and 4 = greatly concerned, where higher scores indicated greater concern about debt. The question has been used previously with medical students, where, in support of validity, debt was associated negatively with well-being and associated positively with perceived career barriers (Rogers et al., 2012).

Hours worked. Trainees were asked, "How many hours per week are you currently working?”, with options of < 35, 35-39, 40-49, 50-59, and 60+ hours.

Career calling. We used the 2-item, presence of calling subscale from the Brief Calling Scale (Dik, Eldridge, Steger, \& Duffy, 2012), which we modified slightly to be directly relevant to medical trainees. The two items were, "I believe that I was meant to be a doctor, i.e., it is my calling”, and "I have a good understanding of my calling as a doctor”. Participants responded on a 5-point Likert-like scale, with anchors of $1=$ not at all true of me and 5 = totally true of me, with higher scores indicating a stronger career calling. Duffy and Sedlacek $(2007,2010)$ reported correlations between the two items of $>.80$, and supported validity by showing positive correlations between the subscale and career development progress, well-being, and life meaning in university students. In our study, the intercorrelation was .70; alpha was .81.

\section{Procedure}

Participants were recruited as part of an ongoing project examining the career development of medical students and post-graduate medical trainees (see Rogers, Searle, Creed, \& Ng, 2010). The data reported in this paper were collected in the last wave of the project, when career calling was examined for the first time. Junior doctors were sent an email, which contained a link to an on-line questionnaire (SurveyMonkey software), inviting their participation. Those who completed the survey were eligible to enter a prize draw for 
the chance to win a store shopping voucher. The study was conducted with the approval of the authors' university ethics committee.

\section{Results}

We used hierarchical multiple regression to test the association between environmental demands (hours worked, academic stress, and concern about debt) and burnout, and to assess if the personal resource of career calling moderated these relations. Burnout was included as the outcome variable, the three environmental demands were included at Step 1, the moderator variable was added at Step 2, and three interaction terms (career calling $\mathrm{x}$ hours worked, career calling x academic stress, career calling x concern about debt) were included at Step 3. No demographic variables were associated with burnout; thus, no control variables were included. The interaction terms were created using products of centred terms (Aiken \& West, 1991). See Table 1 for descriptives and bivariate correlations, and Table 2 for a summary of the regression analysis.

The combined environmental demands at Step 1 accounted for $27.5 \%$ of the variance in burnout, $F(3,351)=44.40, p<.001$, with all variables making unique contributions: academic stress $\left(s r^{2}=17.39 \%, p<.001\right)$, hours worked $\left(s r^{2}=2.72 \%, p<.001\right.$, and concern about debt $\left(s r^{2}=2.68 \%, p<.001\right)$. Career calling at Step 2 explained an additional $1.2 \%$ of variance, $F_{C h}(1,350)=5.66, p=.018$, and one interaction term (career calling $\mathrm{x}$ academic stress) added an extra 3.2\% at Step 3, $F_{C h}(3,347)=5.46, p=.001$. At this final step, academic stress was the most important predictor of burnout, followed by hours worked and debt concern. When considered in the context of the other variables, career calling was not a significant predictor, but did moderate the association between academic stress and burnout. For this interaction term, burnout was higher for both career calling groups when academic stress was higher. As academic stress reduced, burnout reduced for both groups, but reduced 
more markedly for the high career calling group, indicating an advantage for those with a stronger career calling.

\section{Discussion}

We tested if academic stress, hours worked, and concern about debt (considered environmental demands from demands-resources model perspective; Demerouti et al., 2001) were correlates of burnout in junior doctors (Hypothesis 1), and tested if career calling (considered a personal resource in demands-resources model) moderated these associations (Hypothesis 2).

All three demand variables were uniquely associated with burnout, explaining a meaningful $28 \%$ of the variance, with academic stress accounting for almost three times the variance than the other two variables combined. Hours worked has been considered by many to be the main stressor for junior doctors (e.g., Lam, Wong, Ip, Lam, \& Pang, 2010; Levey, 2001), although this was not the case with our sample. This might reflect attempts to reduce working hours for junior doctors, although reports suggest that only marginal reductions in working hours have occurred for Australian medical trainees (Leeder, 2007). Academic stress was the important correlate in this sample. Our questions covered anxiety about performance compared to others, effect of performance on future career, and being overwhelmed by the amount of work required. These concerns have been identified previously (e.g., Dahlin, Joneborg, \& Runeson, 2005), but were not ranked as highly as they were by these junior doctors. This suggests a simple focus on the number of hours worked will not capture the main stressors for these trainees, and interventions should focus on helping them manage the broader academic demands associated with their post-graduate training. For example, providing specific input on problem solving skills and coping strategies might assist junior doctors to better manage the patient and study demands of training hospital environments. 
We found a significant, though weak, negative correlation between career calling and burnout, which was maintained when career calling was considered along with the other variables in the regression analyses. Career calling has been found to be associated with better well-being in a range of populations, including university students (e.g., Duffy \& Sedlacek, 2007) and working adults (e.g., Dobrow, 2012), and related similarly to burnout in adult populations (e.g., Hagmaier \& Abele, 2012). Our study demonstrated an association in junior doctors. This direct association can be expected as career calling can be considered a personal resource that provides life meaning and strengthens resilience and coping in the face of challenge (Elangovan et al., 2010).

The associations between career calling and burnout found in this sample of junior doctors need to be considered in the light of the interaction effect identified. As anticipated, the career calling resource buffered the relationship with one of the environmental demands tested in the study. Having a higher career calling moderated the effect of having higher levels of academic stress, suggesting a protective effect for junior doctors with a stronger career calling. This is understandable, as junior doctors with a stronger sense of purpose and clearer life and career directions should be better placed to manage the demands of postgraduate medical training. Research into the career calling of medical trainees and practitioners is a relatively new area of investigation, and future studies might profitably examine the effect of having a calling on other aspects of medical life. Borges et al. (2013) found that level of career calling differentiated between medical students who were interested in primary care medicine from those who were interested in non-primary care practice. Thus, having a career calling is likely to have wider effects than on well-being.

This study has contributed to the literature by demonstrating that career calling is uniquely associated with better well-being in junior doctors (i.e., lower burnout), and that career calling buffers the effect of at least one training demand (academic stress) on burnout. Our 
study utilised a brief measure of career calling. While this scale has been used widely, future studies might test the study associations using multi-dimensional measures of career calling. Our sample was disproportionately female. Although we found no relation between gender and burnout, future studies need to confirm these results on a larger sample with a more equal gender balance. While we tested a plausible, causative model consistent with the literature (i.e., that the environmental demands and the career calling resource were antecedents to burnout), these associations have to be tested across time. Finally, we assessed a small number of demands, which we identified from the literature. These stressors accounted for about one third of the variance in burnout, meaning that other potential training stressors need to be considered. Despite these limitations, the study points to potential, additional strategies that might assist junior doctors to manage their post-university training, such as helping them clarify their values around their medical calling and helping them strengthen their commitment to it.

Acknowledgements. We would like to thank the Australian Research Council for the financial support provided. 


\section{References}

Abrau Santos, A., Grosseman, S., Oliva Costa E. F., \& Andrade, T. M. (2011). Burnout syndrome among internship medical students. Medical Education, 45, 1146. doi:10.1111/j.1365-2923.2011.04108.x

Aiken, L. S., \& West, S. G. (1991). Multiple regression: Testing and interpreting interactions. Newbury Park, CA: Sage.

Alarcon, G., Eschleman, K. J., \& Bowling, N. A. (2009). Relationships between personality variables and burnout: A meta-analysis. Work \& stress, 23, 244-263. doi:10.1080/02678370903282600

Bakker, A. B., Demerouti, E., Taris, T., Schaufeli, W. B., \& Schreurs, P. (2003). A multigroup analysis of the job demands-resources model in four home care organizations. International Journal of Stress Management, 10, 16-38. doi:10.1037/1072-5245.10.1.16

Borges, N. J., Manuel, R. S., \& Duffy, R. D. (2013). Speciality interests and career calling to medicine among first-year medical students. Perspectives on Medical Education, 2, 1417. doi:10.1007/s40037-012-0037-9

Campbell, J., Prochazka, A. V., Yamashita, T., \& Gopal, R. (2010). Predictors of persistent burnout in internal medicine residents: A prospective cohort study. Academic Medicine, 85, 1630-1634. doi:10.1097/ACM.0b013e3181f0c4e7

Cardador, M. T., \& Caza, B. B. (2012). Relational and identity perspectives on healthy versus unhealthy pursuit of callings. Journal of Career Assessment, 20, 338-353. doi:10.1177/1069072711436162

Colford, J. M., \& McPhee, S. J. (1989). The ravelled sleeve of care: Managing the stresses of residency training. Journal of the American Medical Association, 261, 889-893. doi:10.1001/jama.261.6.889 
Collier, V. U., McCue, J. D., Markus, S. A., \& Smith, L. (2002). Stress in medical residency: Status quo after a decade of reform? Annals of Internal Medicine, 136, 384-390. Retrieved from http://annals.org/

Cooke, M. (1985). Stress and coping in internal medicine residency. The Western Journal of Medicine, 142, 547-548. Retrieved from http://www.ncbi.nlm.nih.gov/pmc/articles/PMC1306095

Correa, F. (2012). School debt a major concern for MED students. Clinical Psychiatry News, 40, 35. Retrieved from http://go.galegroup.com.libraryproxy.griffith.edu.au/ps/i.do?id=GALE\%7CA307790044\& $v=2.1 \& u=$ griffith\&it $=r \& p=H R C A \& s w=w$

Dahlin, M., Joneborg, N., \& Runeson, B. (2005). Stress and depression among medical students: A cross-sectional study. Medical Education, 39, 594-604. doi:10.1111/j.13652929.2005.02176.x

Daly, M. G., \& Willcock, S. M. (2002). Examining stress and responses to stress in medical students and new medical graduates. The Medical Journal of Australia, 177, S14-S15. Retrieved from https://www-mja-com-au

Demerouti, E., Bakker, A. B., Nachreiner, F., \& Schaufeli, W. B. (2001). The job demandsresources model of burnout, Journal of Applied Psychology, 86, 499-512. doi:10.1037/0021-9010.86.3.499

de Oliva Costa, E. F., Santos, S. A., de Abreu Santos, A. T., de Melo, E. V., \& de Andrade, T. M. (2012). Burnout syndrome and associated factors among medical students: A crosssectional study. Clinics, 67, 573-579. doi:10.6061/clinics/2012(06)05

Dik, B. J., \& Duffy, R. D. (2009). Calling and vocation at work. The Counseling Psychologist, 37, 424-450. doi:10.1177/0011000008316430 
Dik, B. J., Eldridge, B. M., Steger, M. F., \& Duffy, R. D. (2012). Development and validation of the Calling and Vocation Questionnaire (CVQ) and Brief Calling Scale (BCS). Journal of Career Assessment, 20, 242-263. doi:10.1177/1069072711434410

Dik, B. J., Sargent, A. M., \& Steger, M. F. (2008). Career development strivings: Assessing goals and motivation in career decision-making and planning. Journal of Career Development, 35, 23-41. doi:10.1177/0894845308317934

Dobrow, S. R. (2012). Dynamics of calling: A longitudinal study of musicians. Journal of Organizational Behavior. doi:10.1002/job.1808

Dobrow, S. R., \& Thosti-Kharas, J. (2011). Calling: The development of a scale measure. Personnel Psychology, 64, 1001-1049. doi:10.1111/j.1744-6570.2011.01234.x

Duffy, R. D., Allan, B. A., \& Bott, E. M. (2012). Calling and life satisfaction among undergraduate students: Investigating mediators and moderators. Journal of Happiness Studies, 13, 469-479. doi:10.1007/s10902-011-9274-6

Duffy, R. D., Dik, B. J., \& Steger, M. F. (2011). Calling and work-related outcomes: Career commitment as a mediator. Journal of Vocational Behavior, 78, 210-218. doi:10.1016/j.jvb.2010.09.013

Duffy, R. D., Manuel, R. S., Borges, N. J., \& Bott, E. M. (2011). Calling, vocational development, and well being: A longitudinal study of medical students. Journal of Vocational Behavior, 79, 361-366. doi:10.1016/j.jvb.2011.03.023

Duffy, R. D., \& Sedlacek, W. E. (2007). The presence of and search for a calling: Connections to career development. Journal of Vocational Behavior, 70, 590-601. doi:10.1016/j.jvb.2007.03.007

Dyrbye, L. N., Harper, W., Durning, S. J., Moutier, C., Thomas, M. R., Massie, F. S., ...Shanafelt, T. D. (2011). Patterns of distress in US medical students. Medical Teacher, 33, 834-839. doi:10.3109/0142159X.2010.531158 
Dyrbye, L. N., Massie, F. S., Eacker, A., Harper, W., Power, D., Durning, S.J., ...Shanafelt, T.D. (2010). Relationship between burnout and professional conduct and attitudes among US medical students. Journal of the American Medical Association, 305, 1173-1180. doi:10.1001/jama.2010.1318

Dyrbye, L. N., Thomas, M. R., Power, D. V., Durning, S., Moutier, C., Massie, S., ...Shanafelt, T. D. (2010). Burnout and serious thoughts of dropping out of medical school: A multi-institutional study. Academic Medicine, 85, 94-102. doi:10.1097/ACM.0b013e3181c46aad

Dyrbye, L. N., Thomas, M. R., Massie, F. S., Power, D. V., Eacker, A., Harper, W., ...Shanafelt, T. D. (2008). Burnout and suicidal ideation among U.S. medical students. Annals of Internal Medicine, 149, 334-341. Retrieved from http://search.proquest.com

Dyrbye, L. N., Thomas, M. R., \& Shanafelt, T. D. (2005). Medical student distress: Causes, consequences, and proposed solutions. Mayo Clinic Proceedings, 80, 1613-1622. doi:10.4065/80.12.1613

Elangovan, A. R., Pinder, C. C., \& McLean, M. (2010). Callings and organizational behaviour. Journal of Vocational Behavior, 76, 428-440. doi:10.1016/j.jvb.2009.10.009

Firth-Cozens, J. (2001). Medical student stress. Medical Education, 35, 6-7. doi:10.1111/j.1365-2923.2001.00832.x

Galán, F., Sanmartín, A., Polo, J., \& Giner, L. (2011). Burnout risk in medical students in Spain using the Maslach Burnout Inventory-Student Survey. Internal Archives of Occupational \& Environmental Health,84, 453-459. doi:10.1007/s00420-011-0623-X

Gelfand, D. V., Podnos, Y. D., Carmichael, J. C., Saltzman, D. J., Wilson, S. E., \& Williams, R. A. (2004). Effect of the 80-hour workweek on resident burnout. Archives of Surgery, 139, 933-940. doi:10.1001/archsurg.139.9.933 
Geurts, S., Rutte, C., \& Peeters, M. (1999). Antecedents and consequences of work-home interference among medical residents. Social Science and Medicine, 48, 1135-1148. doi:10.1016/S0277-9536(98)00425-0

Goldberg, R., Boss, R. W., Chan, L., Goldberg, J., Mallon, W. K., Moradzadeh, D., Goodman, E. A., \& McConkie, M. L. (1996). Burnout and its correlates in emergency physicians: Four years’ experience with a wellness booth. Academic Emergency Medicine, 3, 1156-1164. doi:10.1111/j.1553-2712.1996.tb03379.x

Hagmaier, T., \& Abele, A. E. (2012). The multidimensionality of calling: Conceptualization, measurement and a bicultural perspective. Journal of Vocational Behavior, 81, 39-51. doi:10.1016/j.jvb.2012.04.001

Halbesleben, J. R. (2010). A meta-analysis of work engagement: Relationships with burnout, demands, resources, and consequences. In A. B. Bakker \& M. P. Leiter, Work engagement: A handbook of essential theory and research, (pp. 102-117). New York, NY: Psychology Press.

Hall, D. T., \& Chandler, D. E. (2005). Psychological success: When the career is a calling. Journal of Organizational Behavior, 26, 155-176. doi:10.1002/job.301

Heins, M., Fahey, S. N., \& Leiden, L. I. (1984). Perceived stress in medical, law, and graduate students. Journal of Medical Education, 59, 169-179. doi:10.1097/00001888198403000-00003

Hirschi, A. (2011). Callings in career: A typological approach to essential and optional components. Journal of Vocational Behavior, 79, 60-73. doi:10.1016/j.jvb.2010.11.002

Karasek, R. A. (1979). Job demands, job decision latitude, and mental strain: Implications for job design. Administrative Science Quarterly, 24, 285-308. doi:10.2307/2392498 
Kristensen, T. S., Borritz, M., Volladsen, E. \& Christensen, K. B. (2005). The Copenhagen Burnout Inventory: A new tool for the assessment of burnout. Work \& Stress, 19, 192-207. doi:10.1080/02678370500297720

Kushner R. F., Kessler, S., \& McGaghie, W. C. (2011). Using behavior change plans to improve medical student self-care. Academic Medicine, 86, 901-906. doi:10.1097/ACM.0b013e31821da193

Lam, T. P., Wong, J. G., Ip, M. S., Lam, K. F., \& Pang, S. L. (2010). Psychological wellbeing of interns in Hong Kong: What causes them stress and what helps them. Medical Teacher, 32, e120-e126. doi:10.3109/01421590903449894

Lazarus, R. S., \& Folkman, S. (1984). Stress, appraisal, and coping. New York, NY: Springer.

Leeder, S. R. (2007). Preparing interns for practice in the 21st century. Medical Journal of Australia, 186 (Supplement), 6-8. Retrieved from https://www-mja-com-au

Levey, R. E. (2001). Sources of stress for residents and recommendation for programs to assist them. Academic Medicine, 76, 142-150. doi:10.1097/00001888-200102000-00010

Markwell, A. L., \& Wainer, Z. (2009). The health and wellbeing of junior doctors: Insights from a national survey. Medical Journal of Australia, 191, 441-444. Retrieved from https://www-mja-com-au

Martini, S., Arfken, C. L., Churchill, A., \& Balon, R. (2004). Burnout comparison among residents in different medical specialities. Academic Psychiatry, 28, 240-242. doi:10.1176/appi.ap.28.3.240

Maslach, C., Schaufeli, W. B., \& Leiter, M. P. (2001). Job burnout. Annual Review of Psychology, 52, 397-422. doi:10.1146/annurev.psych.52.1.397 
Oliva Costa, E. F., Santos, A. S., Abreu Santos, A. T., Melo, E. V., \& Andrade, T. M. (2012). Burnout Syndrome and associated factors among medical students: A cross-sectional study. Clinics, 67, 573-579. doi:10.6061/clinics/2012(06)05

Ozyurt, A., Hayran, O., \& Sur, H. (2006). Predictors of burnout and job satisfaction among Turkish physicians. QJM, 99, 161-169. doi:10.1093/qjmed/hcl019

Pesce, A. (2009). Healthy doctors: Better medicine. Speech to 6th National Doctors’ Health Conference Adelaide. Retrieved from http://ama.com.au/node/4934

Prins, J. T., van der Heiden, F. M.M.A., Hoekstra-Weebers, J. E.H.M., Bakker, A. B., van de Wiel, H. B.M., Jacobs, B., \& Gazendam-Donofrio, S. M. (2009). Burnout, engagement and resident physicians’ self-reported errors. Psychology, Health \& Medicine, 14, 654666. doi:10.1080/13548500903311554

QTAC (2013). Course search. Retrieved January 25, 2013, from http://www.qtac.edu.au/Courses/courses/guide2013/020712.htm

Rogers, M. E., Creed, P. A., \& Searle, J. (2012). Person and environmental factors associated with well-being in medical students. Personality and Individual Differences, 52, 472-477. doi:10.1016/j.paid.2011.11.006

Rogers, M., Searle, J., Creed, P. A., \& Ng, S. (2010). A multivariate analysis of personality, values and expectations as correlates of career aspirations of final year medical students. International Journal for Educational and Vocational Guidance, 10, 177-189. doi:10.1007/s10775-010-9182-z

Thomas, M. R., Dyrbye, L. N., Huntington, J. L., Lawson, K. L., Novotny, P. J., Sloan, J. A., \& Shanafelt, T. D. (2007). How do distress and well-being relate to medical student empathy? A multicenter study. Journal of General Internal Medicine, 22, 177-183. doi:10.1007/s11606-006-0039-6 
West, C. P., Huschka, M. M., Novotny, P. J., Sloan, J. A., Kolars, J. C., Habermann, T. M., \& Shanafelt, T. D. (2006). Association of perceived medical errors with resident distress and empathy: A prospective longitudinal study. Journal of American Association, 296, 10711078. doi:10.1001/jama.296.9.1071

Winwood, P., \& Winefield, A. H. (2004). Comparing two measures of burnout among dentists in Australia. International Journal of Stress Management, 11, 282-289. doi:10.1037/1072-5245.11.3.282

Wright, S. M., Levine, R. B., Beasley, B., Haidet, P., Gress, T. W., Caccamese, S., ...Kern, D. E. (2006). Personal growth and its correlates during residency training. Medical Education, 40, 737-745. doi:10.1111/j.1365-2929.2006.02499.x 
Table 1

Summary Data and Bivariate Correlations; $N=355$

\begin{tabular}{|c|c|c|c|c|c|c|c|}
\hline Variables & $M$ & $S D$ & 1 & 2 & 3 & 4 & 5 \\
\hline 1. Burnout & 20.45 & 4.84 & - & $-.12 *$ & $.27 * * *$ & $.18 * *$ & $.47 * * *$ \\
\hline 2. Career calling & 6.50 & 2.09 & & - & .01 & .03 & -.04 \\
\hline 3. Debt concerns & 1.81 & .87 & & & - & .01 & $.22 * * *$ \\
\hline 4. Hours worked & 3.30 & .99 & & & & - & .03 \\
\hline 5. Academic stress & 11.94 & 3.38 & & & & & - \\
\hline
\end{tabular}


Table 2

Hierarchical Multiple Regression Analyses Predicting Burnout in Junior Medical Doctors; $N=355$

\begin{tabular}{|c|c|c|c|c|}
\hline Variables & $B$ & $S E(B)$ & $\beta$ & $R^{2}$ \\
\hline \multicolumn{5}{|l|}{ Step 1} \\
\hline Debt concern & .93 & .26 & $.17 * * *$ & .28 \\
\hline Hours worked & .81 & .22 & $.17 * * *$ & \\
\hline Academic stress & .61 & .07 & $.43^{* * *}$ & \\
\hline \multicolumn{5}{|l|}{ Step 2} \\
\hline Debt concern & .94 & .26 & $.17 * * *$ & .29 \\
\hline Hours worked & .83 & .22 & $.17 * * *$ & \\
\hline Academic stress & .61 & .07 & $.42 * * *$ & \\
\hline Career calling & -.25 & .11 & $-.11 *$ & \\
\hline \multicolumn{5}{|l|}{ Step 3} \\
\hline Debt concern (DC) & .95 & .25 & $.17 * * *$ & .32 \\
\hline Hours worked (HW) & .88 & .22 & $.18^{* * *}$ & \\
\hline Academic stress (AS) & .59 & .07 & $.41 * * *$ & \\
\hline Career calling (CC) & -.11 & .11 & -.05 & \\
\hline $\mathrm{CC} \times \mathrm{DC}$ & -.19 & .23 & -.04 & \\
\hline CC $x$ HW & -.37 & .22 & -.08 & \\
\hline CC $x$ AS & .84 & .22 & $.19 * * *$ & \\
\hline
\end{tabular}




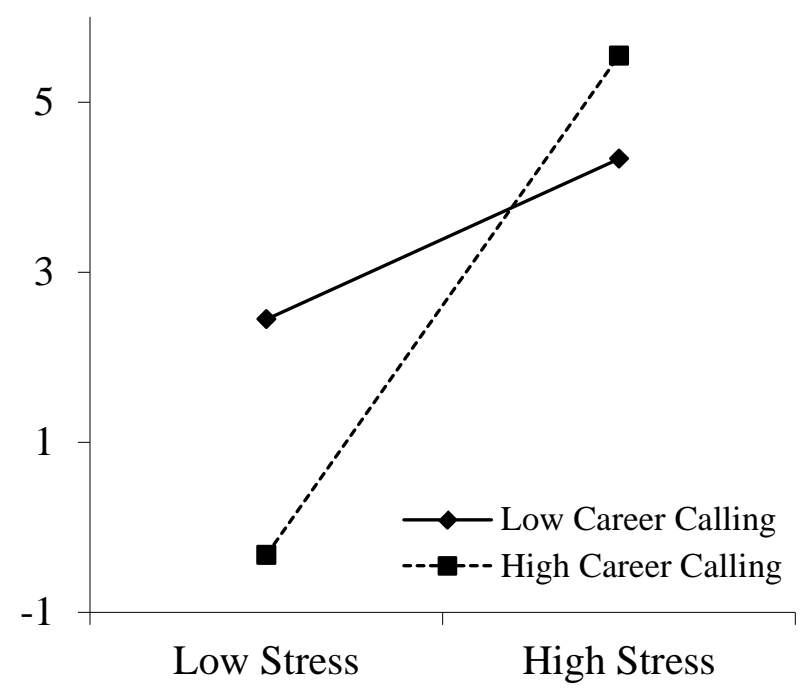

Figure 1. Career calling moderates the association between academic stress and burnout. 